\title{
Congenital simple hamartoma of the retinal pigment epithelium. Incidental finding
}

\section{Hamartoma congénito simple del epitelio pigmentado de la retina}

\author{
Ana Belén González-Escobar ${ }^{1 *}$, Antonio Ramos-Suárez², Francisco José Barrero-Sojo, \\ Mercedes Lorenzo-Soto ${ }^{3}$ and Saturnino Gismero-Moreno ${ }^{1}$
}

${ }^{1}$ Bachelor of Medicine and Surgery, Specialist in Ophthalmology; ${ }^{2}$ Bachelor of Medicine, Internal Medicine resident in ophthalmology; ${ }^{3}$ Doctor of Medicine, Specialist in ophthalmology. Ophthalmology Department, Hospital Costa del Sol, Marbella, Málaga, Spain

\begin{abstract}
Introduction: Congenital simple hamartoma of the retinal pigment epithelium (CSHRPE) is a benign, unilateral and solitary tumor, which is usually located near the macula adjacent to the fovea; it remains unchanged throughout life. Clinical case: A 62-year-old patient diagnosed based on clinic findings and by optical coherence tomography (OCT) of a (CSHRPE) discovered in a routine ophthalmological examination. It remained unchanged in subsequent examinations. Discussion: A correct differential diagnosis of the lesion must be made with other malignant lesions, as well as a correct follow-up for the detection of possible complications, including exudation and retinal contraction. Conclusion: Differential diagnosis of CSHRPE with other types of tumors is very important, and for this OCT is a very helpful diagnostic tool.
\end{abstract}

Key words: Congenital simple hamartoma. Retinal pigment epithelium. Benign retinal tumor. Differential diagnosis. Optical coherence tomography.

\section{Resumen}

Introducción: El hamartoma congénito simple del epitelio pigmentado de la retina (HCSEPR) es un tumor benigno, unilateral y solitario, que suele localizarse cerca de la mácula adyacente a la fóvea, y permanecer invariable a lo largo de la vida. Caso clínico: Paciente de 62 años de edad diagnosticado por la clínica y por la tomografía de coherencia óptica (OCT) de (HCSEPR) descubierto en una exploración rutinaria oftalmológica. Permanece sin cambios en las sucesivas revisiones. Discusión: Debe realizarse un correcto diagnóstico diferencial de la lesión con otras de carácter maligno y un correcto seguimiento, para su despistaje de posibles complicaciones entre ellas la exudación y contracción retiniana. Conclusión: El diagnóstico diferencial de los HCSEPR con otro tipo de tumores es muy importante, para ello nos basamos, sobre todo en la OCT.

Palabras clave: Hamartoma congénito simple. Epitelio pigmentario retiniano. Tumor benigno retiniano. Diagnóstico diferencial. Tomografía de coherencia óptica.

\section{Correspondence:}

*Ana Belén González-Escobar

E-mail: anadupi83@ hotmail.com

Available online: 07-05-2018

Date of reception: 08-05-2016

Date of acceptance: 30-06-2016

DOI: 10.24875/RMOE.M18000008

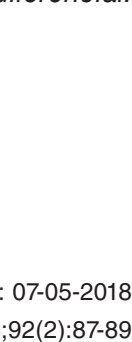
www.rmo.com.mx wwW.rmo.com.mx license (http://creativecommons.org/licenses/by-nc-nd/4.0/). 


\section{Introduction}

Congenital simple hamartoma of the retinal pigment epithelium (CSHRPE) is a benign, unilateral and solitary tumor, which is usually located near the macula adjacent to the fovea, with a diameter less than $1 \mathrm{~mm}$ and from 1-2.5 mm in thickness. In some cases, the nodule can protrude through the neurosensory retina, reaching the vitreous cavity. It is very rare, and there are very few cases described in literature. It was initially described by Laqua in 1981 and later characterized and named by Gass in 1989, who reported 10 cases. In 2003 , Shields also reported an extensive series of cases. Only one of the 15 patients examined by Gass and Shields exhibited poor visual acuity $(\mathrm{VA})^{1,2}$. It is composed almost exclusively of retinal pigment epithelial cells and its origin is congenital. They usually remain unchanged throughout life, and it is very rare that they become malignant. Usually they are associated with mild adjacent traction ( $80 \%$ of cases), retinal exudation (20\% of cases) and pigmented cells in the vitreous cavity $(20 \%$ of cases). They have a minimally dilated nutritious artery and vein $(100 \% \text { of cases })^{3}$.

\section{Clinical case}

A 62-year-old patient was referred by his family doctor due to a pigmented lesion in the right eye observed in a retinography for screening of diabetic retinopathy. On examination, he had a VA of 0.7 in the right eye and 0.6 in the left eye. The intraocular pressure of both eyes was normal. Biomicroscopy evidenced cortical cataracts in both eyes. By fundoscopy a densely pigmented lesion located on the nasal side of the papilla, small and raised was observed in the right eye, without evidence of edema, traction, exudation or subretinal fluid (Fig. 1). Fundoscopy of the left eye was normal. Autofluorescence (AF) was performed, showing hypo-autofluorescence in the area corresponding to the lesion (Fig. 2). Optical coherence tomography (OCT) performed in the lesion showed hyperreflectivity in the internal layers with a posterior shadow (Fig. 1). Once diagnosed with CSHRPE by the clinic and tomographic findings, the patient has been examined periodically without detecting any change in the lesion.

\section{Discussion}

CSHRPE is a benign tumor that is usually diagnosed incidentally. It is a rare tumor that can be detected during routine ocular fundus examination. On clinical

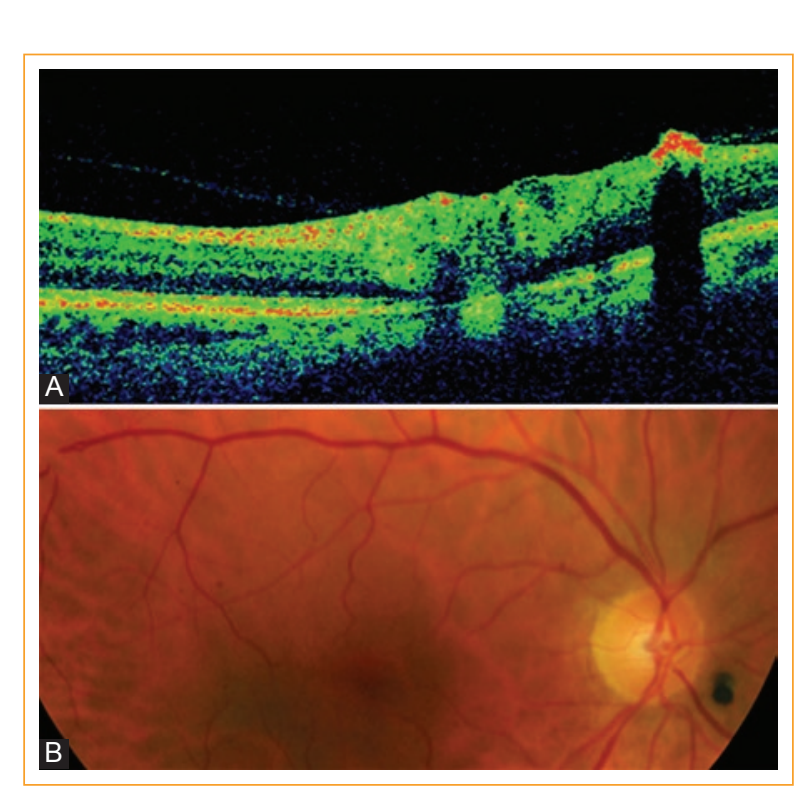

Figure 1. A: OCT showing hyperreflective lesion in the internal layers with a posterior shadow. B: Retinography.

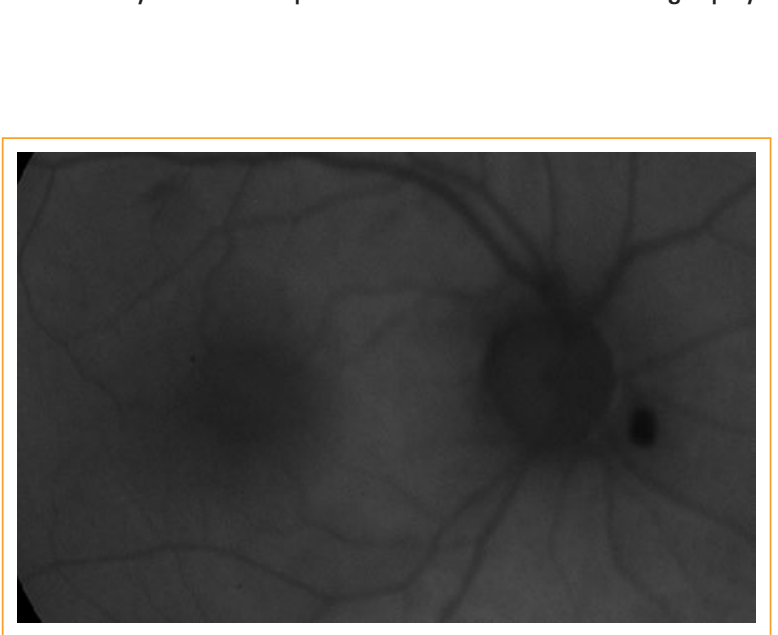

Figure 2. Autofluorescence with a hypo-autofluorescent image of the lesion, located on the nasal side of the papilla.

examination, it appears as a solitary, pigmented, weIl-defined lesion that surrounds all the layers of the retina. ${ }^{1}$ It may be associated with retinal traction, exudation and pigmented cells in the vitreous ${ }^{4}$. Differential diagnosis includes combined hamartoma of the retina and the retinal pigment epithelium (RPE) (full-thickness retinal lesions of charcoal gray color with vascular tortuosity and associated preretinal membranes); congenital hypertrophy of the RPE (flat lesions limited to the plane of the RPE, without retinal invasion); adenoma or adenocarcinoma of the EPR (acquired tumors diagnosed in elderly patients that exhibit a different course, with progressive growth, exudation, subretinal fluid and 
vitreous hemorrhage); RPE hyperplasia (can develop into a full-thickness retinal mass, although scattered mottling of the adjacent RPE is generally observed, and evidence of the cause that induced the hyperplasia); intraocular foreign body (associated with history of ocular trauma, evidence of foci of fibrosis and vitreous traction, showing a posterior acoustic shadow pattern by ultrasound); nevus and choroidal melanoma; epiretinal membranes, etc. ${ }^{1,3,5,6}$. This diagnoses can be ruled out by ancillary tests. Ocular ultrasound shows a nodular echogenic mass of moderate to high internal reflectivity, without a shadow. Fluorescein angiography shows a hypo-fluorescent lesion during the whole angiogram; in some cases, a hyper-fluorescent ring of the lesion can be observed in late phases. Autofluorescence shows hypo-autofluorescence of the lesion ${ }^{4}$. OCT is a noninvasive test that helps the diagnosis, and provides information about tumor characteristics such as hyperreflectivity of the inner layers with a posterior shadow ${ }^{1,3}$.

The treatment, since it usually remains unchanged over time, is observation. In some cases with contraction or an epiretinal membrane, vitrectomy can be performed after benefit-risk assessment and, in cases of macular edema with visual loss; it can be treated with intravitreal injection of an antiangiogenic drug ${ }^{7}$.

\section{Conclusion}

Differential diagnosis of CSHRPE with other types of tumors is very important, and for this OCT is a very helpful diagnostic tool. In addition, a correct follow-up of the lesion must be performed, for observation and screening of possible complications.

\section{Ethical disclosures}

Protection of human and animal subjects. The authors declare that no experiments were performed on humans or animals for this study.

Confidentiality of data. The authors declare that no patient data appear in this article.

Right to privacy and informed consent. The authors declare that no patient data appear in this article.

\section{Funding}

The author(s) received no specific funding for this work.

\section{Conflict of interest}

The authors declare no conflict of interest.

\section{References}

1. Rossi M, Ferreira V, Arana LA, et al. Congenital simple hamartoma of the retinal pigment epithelium: A case report. Arq Bras $\bigcirc$ Oftalmol. 2014;77:114-5.

2. Barnes AC, Goldman DR, Laver NV, et al. Congenital simple hamartoma of the retinal pigment epithelium: Clinical, optical coherence tomography, and histopathological correlation. Eye. 2014;28:765-6.

3. García J. Guía de lesiones pigmentadas del fondo de ojo. Guías de Práctica Clínica de la SERV. Sociedad Española de Retina y Vitreo. 2012. [consultado Mar 2012]. Disponible en: http://www.serv.es.

4. Teke MY, Ozdal PÇ, Batioglu F, et al. Congenital simple hamartoma of retinal pigment epithelium: Clinical and imaging findings. Case Rep Ophthalmol Med. 2012;2012:654-502.

5. Shields CL, Shields JA, Marr BP, et al. Congenital simple hamartoma of the retinal pigment epithelium: A study of five cases. Ophthalmology. 2003:110:1005-11.

6. Shields CL, Manalac J, Das C, et al. Review of spectral domain-enhanced depth imaging optical coherence tomography of tumors of the retina and retinal pigment epithelium in children and adults. Indian $\mathrm{J}$ Ophthalmo. 2015;63:128-32

7. Bach A, Gold AS, Villegas VM, et al. Simple hamartoma of the retinal pigment epithelium with macular edema. Optom Vis Sci. 2015:92:48-50 